\title{
A Retrospective Study on Bacteriology, Clinicopathologic and Radiographic Features in 28 Cats Diagnosed with Pyothorax
}

\author{
Juin Jia Sim ${ }^{1, * \mathbb{D}}$, Seng Fong Lau ${ }^{1,2, *}$, Sharina Omar $^{3}$, Malaika Watanabe ${ }^{1}$ and Muhammad Waseem Aslam ${ }^{1} \mathbb{D}$ \\ 1 Department of Veterinary Clinical Studies, Faculty of Veterinary Medicine, University Putra Malaysia, \\ Serdang 43400, Malaysia; maraika@upm.edu.my (M.W.); dr.waseemaslam@gmail.com (M.W.A.) \\ 2 Laboratory of Cancer Research UPM-MAKNA (CANRES), Institute of Bioscience, University Putra Malaysia, \\ Serdang 43400, Malaysia \\ 3 Department of Veterinary Pathology and Microbiology, Faculty of Veterinary Medicine, University \\ Putra Malaysia, Serdang 43400, Malaysia; sharina@upm.edu.my \\ * Correspondence: simjuinjia@gmail.com (J.J.S.); lausengfong@hotmail.com (S.F.L.); \\ Tel.: +60-16-537-6672 (J.J.S.); +60-3-8609-3927 (S.F.L.)
}

check for updates

Citation: Sim, J.J.; Lau, S.F.; Omar, S.; Watanabe, M.; Aslam, M.W. A Retrospective Study on Bacteriology, Clinicopathologic and Radiographic Features in 28 Cats Diagnosed with Pyothorax. Animals 2021, 11, 2286. https://doi.org/10.3390/ani11082286

Academic Editor: Giacomo Biagi

Received: 9 July 2021

Accepted: 28 July 2021

Published: 3 August 2021

Publisher's Note: MDPI stays neutral with regard to jurisdictional claims in published maps and institutional affiliations.

Copyright: (c) 2021 by the authors. Licensee MDPI, Basel, Switzerland. This article is an open access article distributed under the terms and conditions of the Creative Commons Attribution (CC BY) license (https:// creativecommons.org/licenses/by/ $4.0 /)$.
Simple Summary: The cat is a popular pet in Malaysia. Pyothorax is one of the most common respiratory conditions of cats in Malaysia. The etiological agents, particularly bacteria, of local feline pyothorax cases have never been studied. Therefore, in the present study we aimed to identify the bacteria involved in feline pyothorax cases, detect the antimicrobial susceptibility of the bacteria involved and study the radiographic findings related to these cases. Clinical records of cats diagnosed with pyothorax between 2013 and 2020 were analysed. The cats were presented with respiratory signs. Blood results showed significant inflammatory patterns and radiographs revealed different findings for each cat. The common bacteria and the antimicrobial susceptibility of the bacteria were determined in this study. Reporting the most common bacteria involved will give clinicians useful information that will further help in the selection of appropriate treatment and help clinicians understand the pathogenesis of pyothorax in the Malaysian cat population.

Abstract: This retrospective study aimed to determine the etiological, clinicopathological, and radiographic features and outcome of feline pyothorax cases. Medical records from twenty-eight cats with pyothorax aged from 4 months to 10 years (median 10 months) diagnosed between 2013 and 2020 were reviewed. Dyspnoea (75.0\%), abnormal lung sounds (75.0\%) and open-mouth breathing $(64.3 \%)$ were the predominant respiratory signs. Leucocytosis $(61.5 \%)$, particularly monocytosis $(68.0 \%)$, and hyperglobulinaemia (65.4\%) were among the most prominent findings in blood analysis. Bilateral pleural effusion was found in $67.9 \%$ of the thoracic radiographs. A total of $47.4 \%$ of the cytological samples revealed the presence of bacteria, while all had positive bacterial growth. Pasteurella multocida, E. coli, Streptococcus spp., and Staphylococcus spp. were the predominant aerobic bacteria isolated from pleural effusion samples. A chest tube was placed in $64.3 \%$ of the cats and $66.7 \%$ of cats with chest tubes survived. In total, $46.4 \%$ of cats with pyothorax recovered. Amoxicillinclavulanate was the antimicrobial of choice against aerobic bacteria found in this study and should be given in combination with antimicrobials that cover anaerobic bacteria. Chest tube placement is crucial for treatment success. Cytological results and bacterial culture may not be consistent; thus, bacterial culture should be performed for every case.

Keywords: feline; pyothorax; radiograph; bacteria; antimicrobial resistance

\section{Introduction}

Cats are the most common pets in Malaysian households and live closely with humans. Most Malaysian feline owners own an average of two to three cats, with some having more than 10 cats per household, and they are often managed as semi-roamers [1,2]. Access to the outdoor environment predisposes cats to exposure to infectious agents due 
to increased encounters with other sick or carrier cats [3]. Moreover, a recent survey of a single Malaysian state revealed that only $30 \%$ of the pet population, including cats, were vaccinated against feline herpesvirus-1, feline calicivirus and Chlamydia psittaci [4].

Pyothorax is one of the most commonly seen respiratory conditions among cats in Malaysia. It is defined as the accumulation of septic purulent exudate within the pleural space [5]. More than $80 \%$ of feline pyothorax is caused by mixed anaerobic bacterial infections [6]. Feline pyothorax is associated with polymicrobial infection consisting of obligate anaerobes (such as Clostridium spp., Fusobacterium spp., Bacteroides spp.) and/or facultative aerobic bacteria (which include Pasteurella spp. and Actinomyces spp.) [7,8]. Less than $20 \%$ of cases are caused by non-oropharyngeal bacteria [9,10], such as Escherichia coli, Salmonella spp., Klebsiella spp., Pseudomonas spp., and Nocardia spp. [7], whereas Mycoplasma spp. is a potential cause of pyothorax in kittens [11] and immunosuppressed adults [12].

The underlying etiopathogenesis in feline pyothorax cases is often unclear [13]. The aetiology of most of the cases remained unidentified and post mortem examination was required to identify the etiopathogenesis of these cases [8]. A study of 50 cases of canine and feline pyothorax in the United Kingdom and Ireland reported the underlying cause of pyothorax in only $18 \%$ of the cases [14]. In a retrospective study of 27 cats in Australia, the etiopathogenesis of pleural space infection was identified in $67 \%$ of cats and parapneumonic pyothorax was the greatest hypothesised etiopathogenesis in 15 out of 27 (56\%) cats [13].

Haematogenous or lymphatic spread, direct inoculation through a penetrating bite wound, parasitic migration, parapneumonic spread and foreign-body migration are suggested routes of feline pyothorax infection $[7,8,15]$. Viral upper respiratory infections have been described to play a role in pleuropneumonia or pyothorax in cats, horses and humans by temporarily damaging mucociliary clearance function [16-19]. Commensals of the upper respiratory tract and oral cavity have been identified as the most common causative agents in pyothorax [5].

Clinically, pyothorax cats often manifest with dyspnoea, abnormal lung sounds or muffled heart sounds upon auscultation and other non-specific signs such as inappetence and lethargy. Radiography should be the first-line diagnostic imaging modality for feline pyothorax cases [5]. Radiographic signs such as lung lobe retraction, the enhancement of lobar edges and interlobar fissures are classical signs of pleural effusion [13]. Pleural effusion often has the characteristic of turbid to opaque septic exudates of cream or pale-yellow colour; however, it can also be pink, green or red-tinged. Cytologically, a high nucleated cell count, consisting of more than $85 \%$ degenerated neutrophils, and physiologically, a protein content of more than $30 \mathrm{~g} / \mathrm{L}$ are reported [6]. Thoracocentesis enables the collection of diagnostic specimens and achieves patient stabilisation. The definitive diagnosis of feline pyothorax can be achieved by a cytological examination in combination with bacterial culture [5].

Currently, there is a lack of local data on the most common bacteria involved in feline pyothorax cases. This retrospective study aimed to determine the clinical manifestations, radiographic features, common concurrent conditions (where applicable), associated organisms and survival rate in feline pyothorax cases. This study will provide useful insights into feline pyothorax and help clinicians in the local setting in the selection of antimicrobials for feline pyothorax cases.

\section{Materials and Methods}

\subsection{Patient Data}

Medical records of cats diagnosed with pyothorax from 2013 to 2020 at University Veterinary Hospital, University Putra Malaysia were evaluated. Cases were included if their medical records were complete, two-view thoracic radiographs were consistent with feline pyothorax and bacterial growth was present on culture. Patient data of the cats with pyothorax including sex, breed, management (outdoor, indoor or semi-roamer), single or multi-cat household, vaccine history, number of days with clinical signs before presentation, underlying or concurrent disease and medical history were recorded and analysed. Body 
temperature, weight, body condition score (BCS) and presenting signs of the cats were also evaluated. In addition, complete blood count and serum biochemistry results were retrieved and evaluated where available.

\subsection{Radiographic Findings}

Patients' radiographs were reviewed and evaluated systematically by two veterinarians to reach a consensus using a systematic checklist as suggested in previous study [20]. The checklist consists of abnormalities of extrathoracic structures, pleural space, pulmonary parenchyma and mediastinum (Table 1).

Table 1. Radiographic thoracic abnormalities criteria.

\begin{tabular}{cc}
\hline Compartments & Checklist of Abnormalities \\
\hline Extrathoracic structures & Discontinuity of diaphragm \\
Loss of diaphragm outline \\
Bite wound at cervical area \\
Evidence of tumour/trauma \\
Presence of subcutaneous emphysema \\
Abnormal size of liver
\end{tabular}

\subsection{Pleural Fluid Analysis and Cytological Evaluation}

Data of the cytological evaluation of the pleural effusions were retrieved. Turbidity was graded subjectively from 0 to $4+$, with 0 as crystal clear and $4+$ being the most turbid until newsprint could not be read through the tube. Specific gravity of the specimens was measured using a refractometer. The erythrocyte, protein and leukocyte levels of the pleural effusions were graded semi-quantitatively (negative, 1+ to 4+ scale) using commercial reagent dipsticks (LabStrip U11Plus, 77 Elektronika Kft., Budapest, Hungary) that undergo colour change reaction relative to concentration, which were later read by electronic analyser (DocUReader 2 Pro, 77 Elektronika Kft.). Pleural effusion smear samples stained with Wright's stain and Gram stain were examined microscopically for cellular abnormality, presence of neoplastic cells and infectious agents such as fungal hyphae, yeast cells parasites and/or bacteria.

\subsection{Bacterial Culture and Antimicrobial Susceptibility}

Bacterial culture results and antimicrobial susceptibility profiles of pleural effusion specimens that were collected via thoracocentesis were retrieved. The type of infection 
(either bacterial infection of single or mixed species) was recorded. The samples were cultured on $5 \%$ horse blood and MacConkey agar plate incubated for 24 to $48 \mathrm{~h}$ at $37^{\circ} \mathrm{C}$ in aerobic conditions. Bacteria were identified by performing conventional biochemical tests and the antimicrobial susceptibilities were determined via the Kirby Bauer technique [21].

\subsection{Therapy and Outcomes}

All cats in the study that received antimicrobial(s) treatment were assessed for recovery and outcome based on subsequent visits to the hospital. Owners of the cats were contacted via telephone to obtain information of post-treatment outcomes in cases where they did not return for follow-up appointments. The data were presented as descriptive statistics. The association between survival rate and chest tube placement was analysed using Fisher's exact test. Analysis was achieved using a web-based Fisher's exact test (https: / www. socscistatistics.com/tests/fisher/default2.aspx) (accessed on 8 July 2021), $p$-value of less than 0.05 was considered statistically significant.

\section{Results}

\subsection{Signalment and History}

Twenty-eight cats were diagnosed with pyothorax between 2013 and 2020 and the age of the cats ranged from 4 months to 10 years (median 11 months, mean 23 months), with 16 females (all intact) and 12 males ( 8 intact males, 4 castrated males). Of these 28 cats, 21 were domestic short hair, 2 were Persian crosses, 4 were pure Persians and 1 was Siamese. The median 5-point body condition score of the cats was 2 with a mean body weight of $2.43 \mathrm{~kg}$. Patient signalment, vaccination status, and the management of the patients are presented in Table 2.

Table 2. Patient signalment of 28 cats with pyothorax.

\begin{tabular}{ccc}
\hline Patient Signalment & Number of Cases $(n)$ & Percentage (\%) \\
\hline Male & 8 & 28.6 \\
Intact Male & 4 & 14.3 \\
Castrated Male & & \\
Female & 16 & 57.1 \\
\hline Intact Female & 0 & 0 \\
Spayed Female & & \\
Vaccination & 6 & 78.6 \\
Yes & 22 & \\
No & & 64.3 \\
Access to outdoors & 18 & 21.4 \\
Yes & 6 & 14.3 \\
No & 4 & 21.4 \\
Not sure & & 60.7 \\
\hline Single cat household & 6 & 17.9 \\
Multi-cat household & 17 & \\
Not sure & 5 & \\
\hline
\end{tabular}

From the history of the cats retrieved from owners, concurrent conditions were identified in 15 cats with pyothorax (53.6\%), as seen in Table 3. Seven cats with feline pyothorax $(25 \%)$ had concurrent feline upper respiratory disease. The cats had clinical signs of upper respiratory infection such as ocular or nasal discharge, sneezing, conjunctivitis or had a history of chronic flu. Direct inoculation of bacteria was suspected in four cats (14.3\%). The cats either had healed thoracic wall puncture wounds, cat fight history or the presence of a gangrenous swollen wound resulting from a cat bite. Four cats $(14.3 \%)$ had other concurrent conditions or diseases, where one cat was jaundiced, one had diabetes mellitus, one cat 
was blind and one cat was positive for feline immunodeficiency virus and feline leukaemia virus. One cat $(3.6 \%)$ had a diaphragmatic hernia due to a motor vehicle accident.

Table 3. Concurrent conditions of pyothorax in 28 cats.

\begin{tabular}{ccc}
\hline Concurrent Conditions & Number of Cases $(\boldsymbol{n})$ & Percentage $(\mathbf{\%})$ \\
\hline Concurrent feline upper respiratory disease & 7 & 25.0 \\
Thoracic puncture wounds & 4 & 14.3 \\
Diaphragmatic hernia & 1 & 3.6 \\
Other concurrent condition/disease * & 4 & 14.3 \\
Unknown & 13 & 46.4
\end{tabular}

* One cat had both concurrent feline upper respiratory disease and another condition (positive for feline immunodeficiency virus and feline leukaemia virus), classified into both categories.

\subsection{Clinical Findings}

The mean body temperature during presentation of the cats was $38.3^{\circ} \mathrm{C}(n=25)$, with a range of $35.6{ }^{\circ} \mathrm{C}$ to $41.2{ }^{\circ} \mathrm{C}$. At clinical examination, respiratory signs were the predominant findings compared to other non-specific clinical findings in sick cats. The most frequent clinical presentations were dyspnoea $(75.0 \%)$, harsh or dull lung sound $(75.0 \%)$, open-mouth breathing $(64.3 \%)$, abdominal breathing (57.1\%), tachypnoea (39.3\%), lethargy (39.3\%), anorexia (39.3\%), dehydration (35.7\%) and ocular or nasal discharge $(28.6 \%)$. Other non-specific clinical findings that were documented were pale mucous membranes (25.0\%) and pyrexia (17.9\%) (Table 4). The cats developed clinical signs such as respiratory distress and anorexia one to 30 days (mean of six days) before presentation.

Table 4. Clinical signs of 28 cats with pyothorax.

\begin{tabular}{ccc}
\hline Clinical Signs & Number of Cases $(n)$ & Percentage (\%) \\
\hline Dyspnoea & 21 & 75.0 \\
Harsh/dull lung sound & 21 & 75.0 \\
Open-mouth breathing & 18 & 64.3 \\
Abdominal breathing & 16 & 57.1 \\
Tachypnoea & 11 & 39.3 \\
Lethargy & 11 & 39.3 \\
Hyporexia/anorexia & 10 & 35.7 \\
Dehydration & 10 & 35.7 \\
Ocular/nasal discharge & 8 & 28.6 \\
Pale mucous membrane & 7 & 25.0 \\
Crackle lung sound & 6 & 21.4 \\
Pyrexia & 5 & 17.9 \\
Tachycardia & 5 & 17.9 \\
Cyanotic & 5 & 17.9 \\
Weight loss & 4 & 14.3 \\
Recumbent & 3 & 10.7 \\
Cymph node enlargement & 3 & 10.7 \\
Cough & 2 & 7.1 \\
\hline
\end{tabular}

\subsection{Haematology and Biochemical Results}

Only 27 cats had their haematological and biochemical results evaluated and their means and medians are presented in Table 5 . Of the 27 available haematological results, the most significant abnormalities were monocytosis $(68 \%)$, increased band neutrophils $(68 \%)$, increased segmented neutrophils $(64 \%)$, leucocytosis $(61.5 \%)$, hyperglobulinaemia (65.4\%) and hyperproteinaemia (57.7\%). 
Table 5. Haematological and serum biochemistry parameters of 27 pyothorax cats.

\begin{tabular}{|c|c|c|c|c|c|}
\hline $\begin{array}{c}\text { Parameters } \\
\text { (Number of Samples) }\end{array}$ & $\begin{array}{c}\text { Normal } \\
\text { Reference Range }\end{array}$ & Mean $\pm \mathrm{SE}$ & Median & $\begin{array}{c}n(\%) \text { with } \\
\text { Value }>\text { Upper RL }\end{array}$ & $\begin{array}{c}n(\%) \text { with } \\
\text { Value }<\text { Lower RL }\end{array}$ \\
\hline $\begin{array}{l}\text { Erythrocytes (RBC) } \\
\left(\times 10^{12} / \mathrm{L}\right)(n=26)\end{array}$ & $5-10$ & $7.01 \pm 0.33$ & 7.07 & $0(0)$ & $2(7.7)$ \\
\hline $\begin{array}{l}\text { Haemoglobin } \\
(\mathrm{g} / \mathrm{L})(n=27)\end{array}$ & $80-150 \mathrm{~g} / \mathrm{L}$ & $102.05 \pm 4.41$ & 101.85 & $0(0)$ & $4(14.8)$ \\
\hline $\begin{array}{c}\mathrm{PCV}(\mathrm{L} / \mathrm{L}) \\
(n=26)\end{array}$ & $0.24-0.45$ & $0.28 \pm 0.01$ & 0.29 & $0(0)$ & $5(19.2)$ \\
\hline $\operatorname{CWCC}\left(\times 10^{9} / \mathrm{L}\right)(n=26)$ & $5.5-19.5$ & $26.79 \pm 3.43$ & 24.05 & $16(61.5)$ & $3(11.5)$ \\
\hline $\begin{array}{l}\text { Band neutrophils } \\
\left(\times 10^{9} / \mathrm{L}\right)(n=25)\end{array}$ & $<0.3$ & $1.40 \pm 0.37$ & 0.79 & $17(68)$ & $0(0)$ \\
\hline $\begin{array}{l}\text { Segmented neutrophils } \\
\qquad\left(\times 10^{9} / \mathrm{L}\right)(n=25)\end{array}$ & $2.5-12.5$ & $20.31 \pm 2.74$ & 22.14 & $16(64)$ & $3(12)$ \\
\hline $\begin{array}{l}\text { Lymphocytes }\left(\times 10^{9} / \mathrm{L}\right) \\
\qquad(n=25)\end{array}$ & $1.5-7.0$ & $3.46 \pm 0.52$ & 2.23 & $3(12)$ & $7(28)$ \\
\hline $\begin{array}{c}\text { Monocytes } \\
\left(\times 10^{9} / \mathrm{L}\right)(n=25)\end{array}$ & $0.2-0.8$ & $1.62 \pm 0.23$ & 1.5 & $17(68)$ & $2(8)$ \\
\hline $\begin{array}{c}\text { Eosinophils } \\
\left(\times 10^{9} / \mathrm{L}\right)(n=25)\end{array}$ & $0.1-1.5$ & $0.66 \pm 0.19$ & 0.22 & $3(12)$ & $7(28)$ \\
\hline $\begin{array}{c}\text { Basophils } \\
\left(\times 10^{9} / \mathrm{L}\right)(n=7)\end{array}$ & Rare & $0.0025 \pm 0.0025$ & 0 & - & - \\
\hline $\begin{array}{c}\text { Platelets } \\
\left(\times 10^{9} / \mathrm{L}\right)(n=24)\end{array}$ & $300-700$ & $228.20 \pm 34.92$ & 206 & $0(0)$ & $17(70.8)$ \\
\hline $\begin{array}{l}\text { Nucleated } \\
\text { erythrocytes/100WBC }(n=8)\end{array}$ & Rare & $5.5 \pm 1.83$ & 3.5 & - & - \\
\hline Reticulocytes/100RBC $(n=16)$ & $0.5-1.5$ & $2.91 \pm 1.16$ & 0.5 & $6(37.5)$ & $7(43.8)$ \\
\hline $\begin{array}{l}\text { Plasma Protein } \\
(\mathrm{g} / \mathrm{L})(n=26)\end{array}$ & $60-80$ & $86.85 \pm 2.67$ & 85 & $15(57.7)$ & $0(0)$ \\
\hline $\begin{array}{l}\text { Icterus Index } \\
\text { (Unit) }(n=22)\end{array}$ & $<10$ & $4.30 \pm 1.18$ & 2 & $2(9.1)$ & $0(0)$ \\
\hline $\begin{array}{c}\text { Sodium } \\
(\mathrm{mmol} / \mathrm{L})(n=21)\end{array}$ & $146-156$ & $149.40 \pm 1.66$ & 148.4 & $3(14.3)$ & $6(28.6)$ \\
\hline $\begin{array}{c}\text { Potassium } \\
(\mathrm{mmol} / \mathrm{L})(n=20)\end{array}$ & $3.9-5.5$ & $4.89 \pm 0.17$ & 4.95 & $4(20)$ & $2(10)$ \\
\hline $\begin{array}{c}\text { Chloride } \\
(\mathrm{mmol} / \mathrm{L})(n=21)\end{array}$ & $110-132$ & $112.62 \pm 1.49$ & 112.3 & $0(0)$ & $5(23.8)$ \\
\hline $\begin{array}{c}\text { Calcium } \\
(\mathrm{mmol} / \mathrm{L})(n=2)\end{array}$ & $2.2-2.9$ & $2.15 \pm 0.05$ & 2.15 & $0(0)$ & $1(50)$ \\
\hline $\begin{array}{l}\text { Inorganic phosphate } \\
\quad(\mathrm{mmol} / \mathrm{L})(n=5)\end{array}$ & $1.1-2.8$ & $2.07 \pm 0.23$ & 2.4 & $0(0)$ & $0(0)$ \\
\hline $\begin{array}{c}\text { Urea } \\
(\mathrm{mmol} / \mathrm{L})(n=27)\end{array}$ & $3.0-10.0$ & $10.62 \pm 1.11$ & 8.8 & $13(48.1)$ & $0(0)$ \\
\hline $\begin{array}{c}\text { Creatinine } \\
(\mathrm{mmol} / \mathrm{L})(n=27)\end{array}$ & 60-193 & $79.04 \pm 5.48$ & 80 & $0(0)$ & $8(29.6)$ \\
\hline $\begin{array}{c}\text { ALT } \\
(\mathrm{U} / \mathrm{L})(n=27)\end{array}$ & $10-90$ & $64.62 \pm 16.89$ & 41.6 & $2(7.4)$ & $0(0)$ \\
\hline $\begin{array}{c}\text { GGT } \\
(\mathrm{U} / \mathrm{L})(n=3)\end{array}$ & $<6.0$ & $3.33 \pm 2.03$ & 3 & $1(33.3)$ & - \\
\hline $\begin{array}{l}\text { Total Protein } \\
(\mathrm{g} / \mathrm{L})(n=27)\end{array}$ & $55-75$ & $78.74 \pm 3.06$ & 76 & 15 (55.6) & $1(3.7)$ \\
\hline $\begin{array}{c}\text { Albumin } \\
(\mathrm{g} / \mathrm{L})(n=27)\end{array}$ & $25-40$ & $25.64 \pm 0.82$ & 25.4 & $0(0)$ & $11(40.7)$ \\
\hline $\begin{array}{l}\text { Globulin } \\
(\mathrm{g} / \mathrm{L})(n=26)\end{array}$ & $25-45$ & $53.14 \pm 3.22$ & 48.6 & $17(65.4)$ & $0(0)$ \\
\hline $\mathrm{A}: \mathrm{G}(n=27)$ & $0.5-1.4$ & $0.52 \pm 0.03$ & 0.5 & $0(0)$ & $9(33.3)$ \\
\hline
\end{tabular}

$n=$ number of samples; $\mathrm{RL}=$ reference limit; $\mathrm{RL}=$ red blood cell; $\mathrm{PCV}=$ packed cell volume; $\mathrm{CWCC}=$ complete white cell count; $\mathrm{WBC}$ = white blood cell; $\mathrm{ALT}=$ alanine transaminase; ALP = alkaline phosphatase; GGT = gamma glutamyl transferase; AST $=$ aspartate transaminase; $\mathrm{TP}=$ total protein; $\mathrm{A}: \mathrm{G}=$ albumin:globulin ratio. 


\subsection{Radiographic Findings}

The radiographic findings of 28 cats with pyothorax are summarised in Table 6. As expected, pleural effusion (Figure 1) was the most typical finding in thoracic radiographs of feline pyothorax, present in all cases (100\%), with bilateral pleural effusion $(67.9 \%)$ more frequently found than unilateral pleural effusion (32.1\%). Lung consolidation (75\%), obscured cardiac silhouette $(71.4 \%)$, hepatomegaly (32.1\%), peritoneal effusion $(10.7 \%)$, sternal lymph node enlargement $(7.1 \%)$ and cranial mediastinal lymph node enlargement (3.6\%) were other notable findings on radiographs.

Table 6. Summary of radiographic findings of 28 cats with pyothorax.

\begin{tabular}{ccc}
\hline Radiographic Findings & Number of Cases $(\boldsymbol{n})$ & Percentage (\%) \\
\hline Pleural effusion & 28 & 100 \\
\hline Unilateral & 9 & 32.1 \\
\hline Bilateral & 19 & 67.9 \\
\hline Lung consolidation & 21 & 75.0 \\
\hline Right & 14 & 50 \\
-Cranial & 12 & 42.9 \\
-Medial & 7 & 25 \\
\hline Left & & 42.9 \\
-Cranial & 12 & 17.9 \\
\hline Caudal & 5 & 71.4 \\
\hline Obscured cardiac silhouette & 20 & 32.1 \\
\hline Hepatomegaly & 9 & 10.7 \\
\hline Peritoneal effusion & 3 & 7.1 \\
\hline Vascular pattern & 2 & 3.6 \\
\hline Cranial mediastinal lymph node enlargement & 1 & 7.1 \\
\hline Sternal lymph node enlargement & 2 & 0 \\
\hline
\end{tabular}

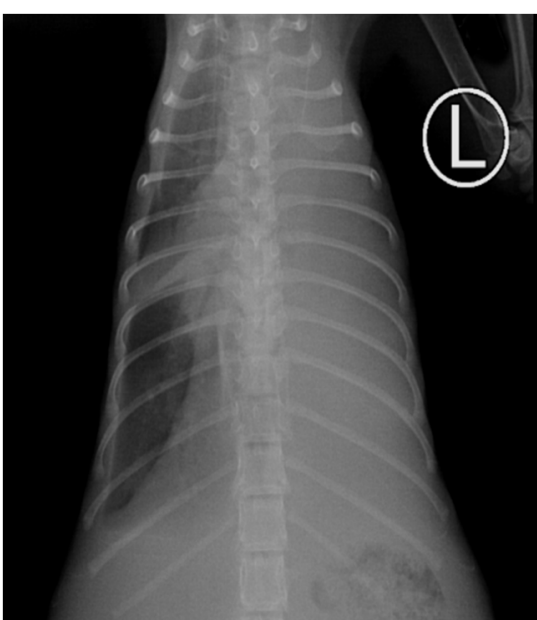

(a)

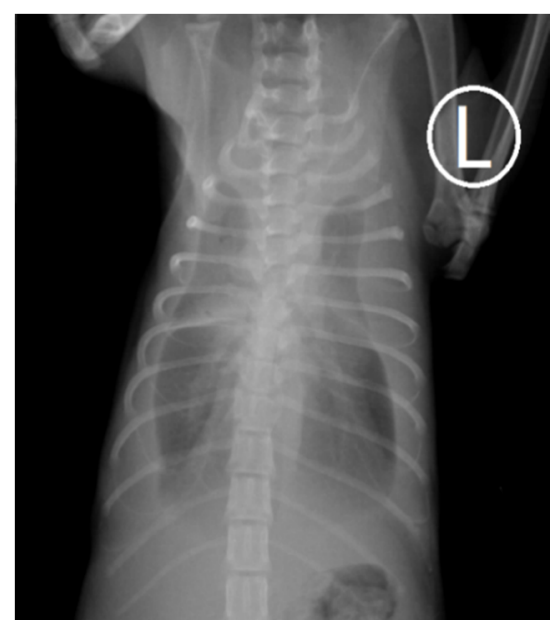

(b)

Figure 1. Ventrodorsal radiographs of feline pyothorax: (a) Unilateral pleural effusion; (b) Bilateral pleural effusion. 


\subsection{Pleural Fluid Analysis and Cytological Evaluation}

Pleural fluid analysis was performed in 19 out of 28 cats with pyothorax. For the appearance of the samples, four were light yellow, seven were milky or creamy light yellow, one was milky light reddish, two milky or whitish, four were pale reddish, one brown reddish and two brownish yellow. One cat had yellow gel-like pleural fluid and tested positive for coronavirus antibodies via an enzyme-linked immunosorbent assay. The $\mathrm{pH}$ of these samples ranged from 5.5 to 8 (mean: 7.0) and the specific gravity ranged from 1.025 to 1.051 (mean: 1.035). All samples fulfilled the criteria of exudate, which is defined by having a specific gravity of more than or equal to 1.025 and constituting predominantly degenerated neutrophils [22]. An erythrocyte level of 3+ to $4+$ (median: $4+$ ), protein level of $2+$ to $4+$ (median $4+$ ), leucocyte level of $1+$ to $3+$ (median $3+$ ), and turbidity level of $1+$ to $4+$ (median $4+$ ) were observed in these samples.

Septic effusions that consist of phagocytosed and free bacteria (coccobacillus/cocci/mixed type) were the most common findings in nine $(47.4 \%)$ out of 19 pleural effusion samples that were examined cytologically. Degenerated neutrophils were the most common cell types observed in 15 samples (78.9\%) (Figure 2). Neoplastic cells, fungal hyphae, yeast cells and parasites were not observed in any of the samples.

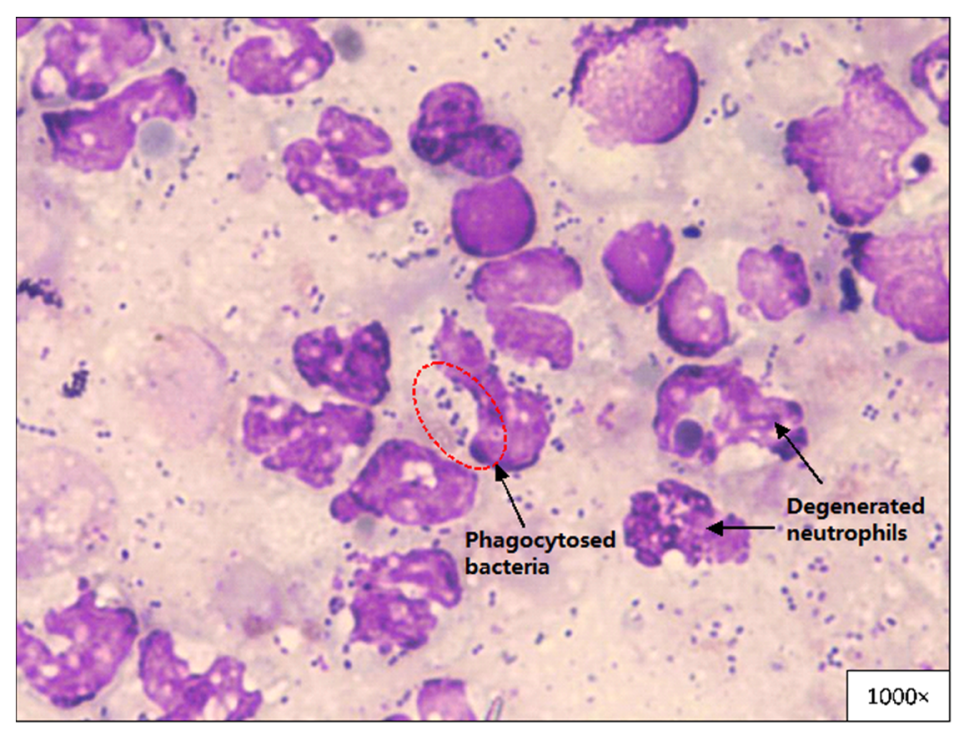

Figure 2. Phagocytosed bacteria and degenerated neutrophils in feline pyothorax pleural effusion sample (Wright's stain).

\subsection{Bacterial Identification and Antimicrobial Susceptibility}

Aerobic bacteria isolated from 28 feline pyothorax cases are presented in Table 7 . The bacteria isolated ranged from $1+$ to $4+$ (mean of $2+$ ). Overall, the most common bacteria identified were Pasteurella multocida, Streptococcus canis and Escherichia coli. Only three cases $(10.7 \%)$ had a mixed infection from multiple bacteria, while the rest of the 25 cases $(89.3 \%)$ were due to a single bacterial species. In terms of bacterial infections of single species, Pasteurella multocida still remained the most common bacterium found. Antimicrobial susceptibility tests performed in 16 of the cases are presented in Table 8. Marbofloxacin demonstrated the highest antimicrobial resistance (71.4\%) in 14 samples. Poor susceptibility was observed with cephalexin at $61.5 \%$ for 13 samples. Amoxicillin-clavulanate showed the lowest antimicrobial resistance at $23.5 \%$ (four out of 17 samples). 
Table 7. Bacteria cultured from 28 cases of cats with pyothorax.

\begin{tabular}{ccc}
\hline Bacteria Cultured & Number of Cases $(\mathbf{n})$ & Percentage (\%) \\
\hline Pasteurella multocida & 9 & 28.12 \\
Streptococcus canis & 5 & 15.63 \\
Escherichia coli & 5 & 15.63 \\
Streptococcus viridans & 2 & 6.25 \\
Staphylococcus pseudintermedius & 2 & 6.25 \\
Streptococcus equi & 1 & 3.13 \\
Staphylococcus intermedius & 1 & 3.13 \\
Methylobacterium mesophilicum & 1 & 3.13 \\
Aggregatibacter actinomycetemcomitans & 1 & 3.13 \\
Neisseria zoodegmatis & 1 & 3.13 \\
Enterobacter cloacae & 1 & 3.13 \\
Acinetobacter lwoffii & 1 & 3.13 \\
Pseudmonas aeruginosa & 1 & 3.13 \\
Fungus-like bacteria & 1 & 3.13 \\
\hline Total number of bacteria identified & 32 & \\
\hline
\end{tabular}

Table 8. Summary of antimicrobial susceptibility tests for 16 cases of cats with pyothorax.

\begin{tabular}{cccc}
\hline Antimicrobials (Number of Samples) & $\begin{array}{c}\text { Disk Content } \\
(\boldsymbol{\mu} \mathbf{g})\end{array}$ & $\begin{array}{c}\text { Resistance } \\
(\mathbf{R}+\mathbf{I})\end{array}$ & $\begin{array}{c}\text { Susceptibility } \\
(\mathbf{S})\end{array}$ \\
\hline Amoxicillin $(n=4)$ & 10 & 3 & 1 \\
Amoxicillin-clavulanate $(n=17)$ & 30 & 4 & 13 \\
Ampicillin $(n=1)$ & 10 & 1 & 0 \\
Azithromycin $(n=2)$ & 15 & 1 & 1 \\
Cephalexin $(n=13)$ & 30 & 8 & 5 \\
Ceftriaxone $(n=8)$ & 30 & 3 & 5 \\
Clindamycin $(n=1)$ & 2 & 1 & 0 \\
Enrofloxacin $(n=14)$ & 5 & 8 & 6 \\
Erythromycin $(n=2)$ & 15 & 1 & 1 \\
Gentamycin $(n=5)$ & 10 & 3 & 2 \\
Marbofloxacin $(n=14)$ & 5 & 10 & 4 \\
Norfloxacin $(n=1)$ & 10 & 0 & 2 \\
Tetracycline $(n=9)$ & 25 & 1 & 5 \\
\hline
\end{tabular}

\subsection{Therapy and Outcomes}

Cats with acute and dyspnoeic presentation were placed in a concentrated oxygen chamber for initial stabilisation. Thoracocentesis or chest tube placement was performed to withdraw the pleural fluid from the cats. Parenteral antimicrobial therapy, intravenous fluid therapy, and serial thoracic radiographs for reassessment of the condition were part of the management of these cases. Antimicrobials were administered for a range of 8 to 30 days (mean 14 days). Among 28 cats with pyothorax, 18 cats $(64.3 \%)$ had chest tube placement, while 10 cats $(35.7 \%)$ had intermittent thoracocentesis. Chest tubes were placed for four to eight days (mean of six days), excluding cases that died before the removal of the chest tube. All cats were treated with a combination of antimicrobial drugs, using more than one route of administration, and a wide range of dosages were used, as presented in Table 9. Based on the available data on the use of antimicrobials in this study, 23 cats were treated with two antimicrobials and five cats with three antimicrobials during the pre-diagnosis management of the cases. One cat died acutely on the day of presentation. The outcomes according to the pre- and post-diagnosis antimicrobials used are presented in Table 10 . 
Table 9. Summary of the details of antimicrobial administration in 28 cats with pyothorax.

\begin{tabular}{cccc}
\hline Antimicrobial & Number of Cases & $\begin{array}{c}\text { Route } \\
\text { Administration }\end{array}$ & Dose (mg/kg) \\
\hline Metronidazole & 21 & IV $/ \mathrm{PO}$ & 10 \\
Amoxicillin-clavulanate & 14 & $\mathrm{SQ} / \mathrm{PO}$ & 12.5 \\
Marbofloxacin & 13 & $\mathrm{IV} / \mathrm{PO}$ & 2 \\
Cephalexin & 4 & $\mathrm{PO}$ & 20 \\
Ceftriaxone & 3 & $\mathrm{IV}$ & 25 \\
Enrofloxacin & 2 & $\mathrm{IV}$ & 5 \\
\hline
\end{tabular}

$\mathrm{IV}=$ intravenous; $\mathrm{PO}=$ per oral; $\mathrm{SQ}=$ subcutaneous.

Table 10. Summary of antimicrobials used in the treatment of 28 pyothorax cats.

\begin{tabular}{|c|c|c|c|c|c|}
\hline Number & $\begin{array}{l}\text { Pre-Diagnosis } \\
\text { (Antimicrobials) }\end{array}$ & $\begin{array}{l}\text { Post-diagnosis } \\
\text { (Antimicrobials) }\end{array}$ & $\begin{array}{l}\text { Number of } \\
\text { Cats }(n=28)\end{array}$ & Outcome $(n=28)$ & Remarks \\
\hline 1 & $\begin{array}{l}\text { Amoxicillin-clavulanate } \\
+ \text { metronidazole }\end{array}$ & - & 10 & $\begin{array}{l}6 \text { died, } 2 \\
\text { euthanised, } 2 \\
\text { recovered }\end{array}$ & $\begin{array}{l}\text { Six cats died in } \\
\text { pre-diagnosed treatment. } \\
\text { Two cats were euthanised } \\
\text { due poor response to } \\
\text { treatment. } \\
\text { Two cats recovered in } \\
\text { pre-diagnosed treatment. }\end{array}$ \\
\hline 2 & $\begin{array}{l}\text { Amoxicillin-clavulanate } \\
+ \text { metronidazole }\end{array}$ & $\begin{array}{l}\text { Remained } \\
\text { amoxicillin- } \\
\text { clavulanate + } \\
\text { metronidazole }\end{array}$ & 1 & 1 recovered & $\begin{array}{l}\text { Bacteria were susceptible } \\
\text { to } \\
\text { amoxicillin-clavulanate. }\end{array}$ \\
\hline 3 & $\begin{array}{l}\text { Amoxicillin-clavulanate } \\
+ \text { marbofloxacin }\end{array}$ & - & 2 & 2 died & $\begin{array}{l}\text { Two cats died in } \\
\text { pre-diagnosed treatment. }\end{array}$ \\
\hline 4 & $\begin{array}{c}\text { Amoxicillin-clavulanate } \\
+ \text { marbofloxacin }+ \\
\text { metronidazole }\end{array}$ & - & 3 & 3 recovered & $\begin{array}{l}\text { Three cats recovered in } \\
\text { pre-diagnosed treatment. }\end{array}$ \\
\hline 5 & $\begin{array}{c}\text { Cephalexin }+ \\
\text { metronidazole }\end{array}$ & - & 1 & 1 died & $\begin{array}{l}\text { One cat died in } \\
\text { pre-diagnosed treatment. }\end{array}$ \\
\hline 6 & $\begin{array}{l}\text { Cephalexin + } \\
\text { metronidazole }\end{array}$ & $\begin{array}{l}\text { Switched to } \\
\text { amoxicillin- } \\
\text { clavulanate }\end{array}$ & 1 & 1 died & $\begin{array}{l}\text { Infection relapsed after an } \\
\text { apparently full recovery, } \\
\text { the owner decided to stop } \\
\text { the treatment. }\end{array}$ \\
\hline 7 & $\begin{array}{l}\text { Cephalexin }+ \\
\text { marbofloxacin }+ \\
\text { metronidazole }\end{array}$ & - & 1 & 1 recovered & $\begin{array}{c}\text { One cat recovered in } \\
\text { pre-diagnosed treatment. }\end{array}$ \\
\hline 8 & $\begin{array}{l}\text { Ceftriaxone }+ \\
\text { enrofloxacin }+ \\
\text { metronidazole }\end{array}$ & - & 1 & 1 recovered & $\begin{array}{l}\text { Cat recovered in } \\
\text { pre-diagnosed treatment. }\end{array}$ \\
\hline 9 & $\begin{array}{l}\text { Enrofloxacin }+ \\
\text { metronidazole }\end{array}$ & - & 1 & 1 died & $\begin{array}{l}\text { The cat died on the day of } \\
\text { presentation. }\end{array}$ \\
\hline 10 & $\begin{array}{l}\text { Marbofloxacin }+ \\
\text { metronidazole }\end{array}$ & - & 6 & 2 died, 4 recovered & $\begin{array}{l}\text { Two cats died in } \\
\text { pre-diagnosed treatment. } \\
\text { Four cats recovered in } \\
\text { pre-diagnosed treatment. }\end{array}$ \\
\hline 11 & $\begin{array}{l}\text { Marbofloxacin + } \\
\text { metronidazole }\end{array}$ & $\begin{array}{c}\text { Remained } \\
\text { marbofloxacin }+ \\
\text { metronidazole }\end{array}$ & 1 & 1 recovered & $\begin{array}{c}\text { Bacteria were susceptible } \\
\text { to marbofloxacin }\end{array}$ \\
\hline
\end{tabular}

Successful treatment was defined as the absence of recurrence at the time of reevaluation two weeks after the last pyothorax treatment. Of the 28 cats that had pyothorax, 
13 cats survived (46.4\%) and the other 15 cats died (53.6\%) at time of re-evaluation. Among the 18 cats that had chest tube placement, 12 cats $(66.7 \%)$ survived. Comparatively, the survival rate was lower in cats that did not have a chest tube placed, where only one $(10 \%)$ out of 10 cats survived. The survival rate of the cats with chest tube(s) was statistically significant $(p=0.006)$. Both unilateral and bilateral types of pleural effusion had similar survival rates at $44.4 \%$ and $47.4 \%$, respectively. The most successful combination of treatments with good prognosis was the usage of chest tube lavage with sterile $0.9 \% \mathrm{NaCl}$ solution. The outcomes for 28 cats are presented in Table 11. From the 18 cats that had chest tube drainage, 11 cats $(61.1 \%)$ had complications as presented. Among 11 cats that developed complications, two (18.2\%) cats did not survive. The most common complications seen among the cats were the development of lung bullae (27.3\%) and subcutaneous emphysema $(27.3 \%)$ (Table 12). From the clinical records, there were eight cases that did not turn up for scheduled check-up.

Table 11. Case outcome of the cats across different treatments or conditions.

\begin{tabular}{ccc}
\hline Status $(\boldsymbol{n}=\mathbf{2 8})$ & Number of Cases $(\boldsymbol{n})$ & Percentage $\boldsymbol{n} \mathbf{( \% )}$ \\
\hline Survived & 13 & 46.4 \\
Dead & 15 & 53.6 \\
\hline Cats with chest tube & 18 & 64.3 \\
\hline Survived & 12 & 66.7 \\
Dead & 6 & 33.3 \\
\hline Cats without chest tube & 10 & 35.7 \\
\hline Survived & 1 & 10.0 \\
Dead & 9 & 90.0 \\
\hline Cats with unilateral pleural effusion & 9 & 32.1 \\
\hline Survived & 4 & 44.4 \\
Dead & 5 & 55.6 \\
\hline Cats with bilateral pleural effusion & 19 & 67.9 \\
\hline Survived & 9 & 47.4 \\
Dead & 10 & 52.6 \\
\hline
\end{tabular}

Table 12. Complications of chest tube placement and thoracic lavage.

\begin{tabular}{ccc}
\hline Complication $(\boldsymbol{n = 1 1 )}$ & Number of Cases $(\boldsymbol{n})$ & Percentage $(\mathbf{\%})$ \\
\hline Lung bullae & 3 & 27.3 \\
Subcutaneous emphysema & 3 & 27.3 \\
Infection at site of chest tube placement & 3 & 27.3 \\
Pneumothorax & 2 & 18.2 \\
Failure of recovery of instilled lavage & 2 & 18.2 \\
Leakage of pleural fluid & 1 & 9.1 \\
Displaced chest tube & 1 & 9.1 \\
\hline
\end{tabular}

\section{Discussion}

In this study, 28 cases of feline pyothorax were reviewed. The age of recruited cats in this study ranged from 4 months to 10 years (mean of 23 months), which was younger than that in previous studies $[7,8,14]$. Male and female cats were equally represented, while domestic short hair cats were over-represented in this study. It has also been reported in previous studies that there is no breed or sex predisposition for feline pyothorax [22].

Most of the pyothorax cats in this study were from multi-cat households $(60.7 \%)$ and had access to the outdoors $(64.3 \%)$. Both multi-cat households and the outdoor environment increase the chance of contact and exposure to other cats. This increases the risk of upper respiratory disease transmission from one cat to another. The aspiration of oropharyngeal 
flora, subsequent colonisation of the lower respiratory tract and direct extension of infection from bronchi and lungs was the most common mechanism proposed in feline pleural space infection [7], human empyema [23] and equine pleuropneumonia [24]. Out of the 28 pyothorax cats, seven $(25 \%)$ were found to have concurrent feline upper respiratory infection. Similar findings were found in another study where $30 \%$ of the pyothorax cats also had typical history or clinical signs of upper respiratory tract infection [7]. Nearly $80 \%$ of the pyothorax cats in this study did not have updated vaccination status against feline herpesvirus and feline calicivirus, making them vulnerable to feline upper respiratory disease. Immunosuppression from the initial upper respiratory virus infection may allow secondary bacterial infection that may invade through compromised lung parenchyma, resulting in bacterial pneumonia. The inflammatory response will initiate the release of oedematous and exudative fluid, protein and neutrophils into the pleural space. Extensive complex parapneumonic diffusion may develop into pyothorax when the formation of pus is sufficient $[5,9,22]$. These findings suggest the antecedent role of upper respiratory infection in pyothorax.

Cats that live in multi-cat households or those that have outdoor access would experience greater inter-cat aggression, and thus a greater chance of fighting and biting, leading to puncture wounds. Thoracic puncture wounds were the second most common concurrent condition among the pyothorax cats. Cats with a history or presence of thoracic puncture wounds were only identified in four cases $(14.3 \%)$, which is similar to findings of a large-scale retrospective study of 80 cats [8]. The result of this study contests the widespread belief that direct inoculation of the pleural cavity by bite wounds through the thorax is the most common aetiology of feline pyothorax. The direct inoculation of oral flora such as Pasteurella spp. into the thorax is possible via a bite wound. The bacteria are introduced into the thoracic cavity, causing septic inflammation. Viruses such as feline immunodeficiency virus (FIV) and feline leukaemia virus (FeLV) can also be transmitted through biting and may cause immunosuppression. Taking into consideration both facts, the association between retroviruses and pyothorax and the immunosuppressive effect of FIV and FeLV might be worth investigating. Previous studies in the United States, the UK, America and Australia reported that 2.86-5.88\% pyothorax cats were FIV positive, while $4.35-4.41 \%$ pyothorax cats were FeLV positive [8,22]. Given the fact that not all the cats in this study underwent viral testing and only one cat was positive for FIV and FeLV, an association between FIV, FeLV and feline pyothorax was not able to be drawn.

Four cats (13.8\%) had other concurrent conditions that may also compromise the immune response of the cats. One cat tested positive for FIV and FeLV. Two cats had systemic conditions or diseases such as jaundice and diabetes mellitus, respectively, while another cat was blind and malnourished since it was young. These conditions may suppress their immune system, making them vulnerable to secondary bacterial infection and increasing their chance of developing pyothorax.

The duration of clinical signs of pyothorax cats prior to diagnosis is very much dependent on the owner's observation. Clinical signs were observed one to 30 days before presentation (mean of six days), similar to a previous report by Barrs et al. [7]. Dyspnoea (75\%), harsh or dull lung sounds (75\%) and open-mouth breathing (64.3\%) were the most common clinical signs among the pyothorax cats. Non-specific clinical signs of feline pyothorax such as inappetence, lethargy, poor body condition, dehydration and, less frequently, coughing are often subtle and go mostly unnoticed by owners. Dyspnoea, which was commonly observed in the present study, is in contrast to another study that reported dyspnoea was overlooked by up to $40 \%$ of the owners of pyothorax cats [9]. Pleural effusion has to become severe enough to give rise to respiratory distress for owners to notice a problem [8]. Furthermore, cats tend to hide clinical signs of the disease well, showing minimal signs of pain and discomfort in the presence of humans, other animals or in stressful conditions, making it difficult for owners to notice these subtle signs of disease. Most of the cats in this study had access to the outdoors or lived in a multi-cat household. Thus, picking up subtle changes or abnormalities in these cats would prove to be harder 
for owners. Besides, it is also possible that the owners were not aware of the clinical signs of pyothorax and what to look out for.

Complete blood count and serum biochemistry analysis are part of the minimum database to access the general condition of the patient and guide therapeutic management of feline pyothorax. Monocytosis (68\%) and leucocytosis (61.5\%) were among the most common abnormal haematological findings in this study, similar to what has been reported previously. Monocytes are released into the circulatory pool as an immune response towards chronic inflammation or stress $[25,26]$. Only one cat had degenerative left shift where the band neutrophil count exceeded the segmented neutrophils. The cat had a poor prognosis and was dead within $24 \mathrm{~h}$ after presentation. Serum biochemical parameters such as hypoalbuminemia ( $40.7 \%$ ) and hyperglobulinaemia $(65.4 \%)$ were also observed. Increased permeability of vessels due to inflammation causes albumin to escape into the pleural cavity, resulting in hypoalbuminemia [27]. During acute phase reaction, hepatic production of albumin is decreased and that of $\alpha$ - and $\beta$-globulin is increased, causing hyperglobulinaemia. Only nine out of 27 cases showed an albumin to globulin ratio (A:G) that was lower than 0.5 , though more cases with such findings were expected due to inflammation in feline pyothorax. The explanation of this finding would be that the majority of the cats were dehydrated and therefore had a greater albumin level, influencing the A:G ratio. In 10 cases, urea was increased by less than one-fold, which may be explained by pre-renal azotaemia. This condition can be explained by the dehydration condition faced by the pyothorax cats, similarly to the previous report of pyothorax cats [28]. There was also one case that had a one-fold increment and another case with a two-fold increment, respectively. Similarly, mild non-regenerative anaemia, mild lymphocytosis, severe neutropenia, thrombocytopenia and slightly elevated urea have also been reported in another study [29]. The complete blood count and serum biochemistry findings of these cases are general findings of inflammation and not specific for pyothorax.

Thoracic radiography is indicated in cases of animals that present with breathing difficulty. In total, $67.9 \%$ of the cats in this study had bilateral effusion, similar to various previous studies $[7,8,14]$. Pleural fluid may remain unilateral if the pleural fluid is too viscous, the mediastinal pleura is not fenestrated or fenestration becomes closed due to inflammation or plugging $[15,30,31]$. Thus, unilateral effusion may remain unilateral or progress to a bilateral distribution. The main significance of unilateral or bilateral effusion is in the treatment. A unilateral chest tube is indicated when unilateral effusion is present and if effective drainage can be accomplished, leaving minimal residual effusion with only one tube [13]. Bilateral chest tubes are indicated in cases of bilateral effusion [10]. Bilateral chest tubes are more likely to give effective drainage in cases of persistent loculation of fluid [32].

In comparison to radiography, computed tomography would yield a more detailed assessment of underlying parenchymal and pleural abnormalities, avoid the superimposition of images, provide details with regard to severity and provide an opportunity for the assessment of mediastinal, sternal and tracheobronchial lymph node enlargement [9]. A previous study reported that computed tomographic attenuation values can be a possible predictor of the type of pleural fluid [33,34]. Nevertheless, this method might not be feasible and can be inconsistent in sensitivity due to the technological and technical difference of the respective computed tomography scanner used. The use of computed tomography as a diagnostic tool would be also risky as the patient has to undergo general anaesthesia and often these patients suffer from respiratory compromise. On the other hand, thoracic ultrasonography is a diagnostic tool that is able to detect moderate to large volumes of pleural effusion without imposing anaesthetic risk on patients with respiratory compromise [13]. Pulmonary foreign bodies, intrathoracic masses, and pulmonary abscesses can sometimes be detected via ultrasonography. Ultrasound-guided thoracocentesis is a tool for both diagnosis and treatment, allowing the evaluation of pleural fluid and the drainage of the pleural fluid. Although grass awns were not recorded in any of the cases in the present study, migrating grass awns can be a potential cause of pleural effusion in cats. 
However, radiographic changes are not very sensitive for such migrating foreign bodies. Computed tomography and bronchoscopy are more sensitive to diagnose them [35].

Pleural fluid analysis and cytology evaluation in this study reported a mean specific gravity of 1.025 to 1.051 (mean 1.035), septic effusions that consisted of phagocytosed and free bacteria (coccobacillus/cocci/mixed type) were found in nine $(47.4 \%)$ cases and degenerated neutrophils were observed in 15 samples $(78.9 \%)$. The results in this study are similar to the pleural fluid analysis in previously reported cases in cats $[7,14]$. Gram staining and cytological examination of pleural fluid allows quick assessment for the presence of bacteria and this assessment can assist the selection of empirical antimicrobial treatment before a culture and susceptibility result is out [22].

Cytologically, bacteria were seen in nine out of 17 samples $(47.4 \%)$, while all samples $(100 \%)$ had positive bacterial culture results. As shown in this study, the cytological visualisation of bacteria from pleural fluid specimens of feline pyothorax and results of bacterial culture may not always be consistent. Thus, bacterial culture should be performed in every case and cytological results should always be compared to the culture results [9].

The most common single bacterium involved in this study was Pasteurella spp., while mixed bacterial infections involved both Staphylococcus spp. (two cases) and Streptococcus spp. (two cases). Despite the majority of the cases involving single bacteria $(89.3 \%)$, more bacteria were suspected to be involved in the cases. Taking the fact that these cases were presented at the hospital as referral cases, it is highly possible the cases had antimicrobial treatment before being referred. False negatives were also suspected if there was insufficient growth of certain isolates in vitro or fastidious bacteria such as anaerobes and Mycoplasma spp. [9]. A study reported that mixed isolates of oropharyngeal flora are often involved in feline pyothorax, primarily consisting of Bacteroides spp., Clostridium spp., Streptococcus spp., Mycoplasma spp., and Pasteurella spp. [10]. About 20\% of feline pyothorax cases were caused by an infectious agent other than oropharyngeal flora, such as Rhodococcus equi, Nocardia spp., Klebsiella spp., Proteus spp. And Pseudomonas spp. [9]. Comparing pyothorax cases in cats and dogs, mixed microbial infections are common in both species $[5,36]$. Isolated Gram-negative, facultative anaerobic rods are predominantly non-enteric in origin in cats, while they have an enteric origin in dogs [9]. Similar to animal studies, mixed aerobic and anaerobic bacteria are commonly isolated from human patients. Aerobic organisms such as Escherichia coli, Haemophilus influenza and Klebsiella pneumoniae and the anaerobic bacterium Bacteroides fragilis are commonly isolated [37].

In general, the most common bacteria identified in this study were Pasteurella multocida (28.1\%), Streptococcus canis (15.6\%) and Escherichia coli (15.6\%). Pasteurella spp. is a commensal bacterium and part of the natural flora of the feline nasopharynx and upper respiratory tract [38]. The inhalation of droplets secreted from the upper respiratory tract or infection via a bite wound are both possible routes of infection [39]. A study reported that Streptococcus canis has been isolated from the nasal cavity in up to $10 \%$ of cats suffering from chronic upper respiratory disease [40]. Streptococcus canis infection is usually opportunistic in older cats due to wounds, immunosuppression or viral infection and it is more prevalent with exposure to grass awns [41]. Streptococcus canis was the second most common isolate of the pyothorax cats. The findings in this study are in contrast to other studies that claimed that Streptococcus canis were not isolated in pleural fluid samples of pyothorax cats $[14,36]$. This could be explained by the stress faced by cats that are from a multi-cat household setting and are exposed to the outdoors, thus causing immunosuppression and allowing this opportunistic pathogen to thrive. Escherichia coli is a member of the Enterobacteriaceae family, which are known to be natural inhabitants of the gastrointestinal tract, oesophagus or mouth of dogs and cats [38]. E. coli is the most important bacterial pathogen of extraintestinal infection, including the urinary, respiratory and reproductive system in both dogs and cats [42]. In this study, E. coli were isolated in five out of 16 pleural samples $(31.25 \%)$, contrary to studies that claimed that Enterobacteriaceae such as E. coli were relatively uncommon and rarely isolated $(0-7 \%)[7,14,36]$. E. coli is a well-recognised multi-sectoral indicator of antimicrobial resistance, and extraintestinal $E$. coli infections are 
often reported to be pathogenic in nature [43-45]. Thus, the detection of E. coli in this study raises concerns of antimicrobial resistance.

Pasteurella multocida, Streptococcus canis and E. coli are zoonotic bacteria. It has been reported that $P$. multocida infection may result in septicaemia, meningitis, brain abscess, pneumonia, endocarditis, and systemic infection [38]. A woman was reported to experience septic shock, sinusitis and pneumonia from P. multocida post cat exposure and cat scratches [46]. A P. multocida isolate was recovered from the urine of a woman with a urinary tract infection, showing molecular evidence of zoonotic transmission from the patient's cat [47]. The zoonotic transmission of P. multocida is possible via aerosol inhalation and contact with pet secretion. Another study reported a case of a geriatric woman with pneumonia that resulted from non-traumatic transmission of $P$. multocida from a domestic dog [48]. S. canis is a member of Lancefield group G streptococcus and it could be pathogenic to humans, since their physiological and biological characteristics are very much like those of group A streptococci. It is also interesting to note that $47 \%$ of group G streptococci isolates from cats were reported to be capable of growing in human blood [49]. E. coli consist of various strains that are distinctively different epidemiologically and phylogenetically, affecting any organ or anatomical site. In humans, E. coli are capable of causing meningitis, septicaemia and urinary tract infections. Animals are recognised as crucial reservoirs of potential sources of extraintestinal pathogenic E. coli [44,50].

In the human context, Streptococcus spp. (e.g., S. intermedius), Staphylococcus spp. (e.g., S. aureus), and Gram-negative aerobes such as E. coli and Haemophilus influenzae were cultured from human community-acquired and hospital-acquired pleural infection. Similarly, some isolates were also found in cats [7,51]. Human empyema, which was caused by staphylococci, enterobacteria, enterococcus and Pseudomonas aeruginosa, has been reported in the United Kingdom [52].

This study has highlighted a major concern of antimicrobial resistance in feline pyothorax cases. Only five (amoxicillin-clavulanate, ceftriaxone, sulfamethoxazole/trimethoprim, norfloxacin, tetracycline) out of 16 antimicrobials tested had a susceptibility of above $50 \%$, but the sample size was limited. The exposure of bacteria to antimicrobials may lead to the selection of resistance; therefore, identification and antimicrobial susceptibility testing are recommended in every case of feline pyothorax. Among the antimicrobials that underwent susceptibility testing, amoxicillin-clavulanate was susceptible in 13 out of 17 samples $(76.5 \%)$. This study provided evidence of amoxicillin-clavulanate being the antimicrobial of choice against aerobic bacteria that were isolated in this study while pending the result of culture and antimicrobial susceptibility testing.

Comparing the antimicrobial susceptibility across the three most common bacteria isolated in the cases, namely P. multocida, E. coli, and S. canis, amoxicillin-clavulanate remained the recommended antimicrobial of choice against aerobes in this study. On average, amoxicillin-clavulanate demonstrated an antimicrobial susceptibility of 50\% to $100 \%$ towards the bacteria mentioned earlier, but the sample size was limited. Enrofloxacin is the antimicrobial often chosen in cases of feline pyothorax at veterinary clinics in Malaysia. Although enrofloxacin has been recommended to be added as an antimicrobial for improved Gram-negative coverage while pending culture results, antimicrobial susceptibility testing in this study revealed that eight out of 14 samples tested against enrofloxacin were resistant. Thus, this again is of major concern and enrofloxacin antimicrobial resistance should be taken into consideration by clinicians.

Different levels of antimicrobial susceptibility have been reported in various countries. In a comprehensive study across Europe, antimicrobial susceptibility levels of $54.6 \%$ to $100 \%$ were reported across different antimicrobials and bacteria [53]. Another retrospective study of pyothorax in the United States revealed an antimicrobial susceptibility of 80 to $100 \%$ towards Pasteurella multocida and Escherichia coli [36]. The level of antimicrobial resistance was different than what was found in our study. Although antimicrobial resistance is largely attributed to indiscriminate use as growth promoters in farm animals [54,55] and the widespread use of quaternary ammonium disinfectants [56], nevertheless, the 
unreasonable use of antibiotics by pet owners, the limited surveillance and control of antimicrobial usage in companion animals, and the paucity of data on local antimicrobial resistance profiles and guidelines on rational antimicrobial usage in companion animals may have also contributed to the emergence of antimicrobial resistance [57,58]. The use of different methods for antimicrobial susceptibility testing and different breakpoints for the evaluation of the results in different countries may vary greatly, thus resulting in different levels of antimicrobial susceptibility according to the country [57].

In this study, among the combination of antimicrobials used, metronidazole was the most common antimicrobial used (21 out of 28 cases), followed by amoxicillin-clavulanate (14 out of 28 cases) and marbofloxacin (13 out of 28 cases). Our choice of antimicrobials for pyothorax is in line with Australasian Infectious Disease Advisory Panel Antibiotic Prescribing Detailed Guidelines and Antimicrobial Guidelines Working Group of the International Society for Companion Animal Infectious Disease [16,59]. Some studies stated that empiric therapy for pyothorax with Gram-negative facultative bacteria should include aminoglycosides (gentamicin or amikacin) or fluoroquinolones [36,60]. The usage of aminoglycoside was discouraged by another study due to poor penetration into the pleural space and potential nephrotoxic and ototoxic effects [61]. Thus, aminoglycoside was not the choice of antimicrobial utilised by the clinicians in this study.

Antimicrobial selection should be based on the identification and susceptibility of the organism in every case of feline pyothorax to prevent the development of antimicrobial resistance, which was seen in these cases. Isolation, the identification of bacteria via biochemical tests and antimicrobial susceptibility testing take a minimum of 3 days. Based on the antimicrobial susceptibility testing, amoxicillin-clavulanate showed the lowest antimicrobial resistance at $23.5 \%$ (four out of 17 samples). Amoxicillin-clavulanate is the recommended antimicrobial against the aerobic bacteria that were found in this study and it is to be given in combination with antimicrobials that cover anaerobic bacteria. Awareness and knowledge of antimicrobial usage and antimicrobial resistance should be promoted. In Malaysia, pet owners tend to visit other clinics easily and demand different treatment for their pet when the owners do not see an improvement in a short period of time. Veterinarians might feel stressed as owners would question the veterinarians' competency in treating the patients when the owners' expectations were not met. Antimicrobial resistance may occur when the owner does not comply with the treatment plan, fails to administer the antimicrobial at the correct dosage or frequency, fails to complete the initial antimicrobial course, or when a new type of antimicrobial is introduced by the second vet.

Intravenous antimicrobials were administered as initial and ongoing treatment and then substituted with oral antimicrobials after the patient was eating well or discharged from hospital in this study, similar to what has been proposed in a previous study [32]. The patients were treated with antimicrobials with a range of 8 to 30 days (mean duration of 14 days). Antimicrobials in this study were dispensed weekly together with a scheduled re-evaluation after the last treatment. Unfortunately, eight owners in this study did not turn up for the scheduled check-up, which may have resulted in antimicrobial treatments being stopped abruptly. Generally, a high dose of antimicrobials for extended periods of time such as oral antimicrobials for a minimum of 3 weeks and ideally a duration of 4-6 weeks is recommended as feline pyothorax is associated with devitalised tissue and relapse is common if treatment is discontinued too early $[7,36,41,60]$.

All 28 cats in this study were treated with a combination of antimicrobials. Three cats from combination number 4 (amoxicillin-clavulanate + marbofloxacin + metronidazole) and four out of six cats from combination number 10 (marbofloxacin + metronidazole) recovered from pyothorax. All recovered cats in both combinations had at least one antimicrobial that had coverage against aerobic bacteria and another for anaerobic bacteria. All recovered cats that were treated with those antimicrobial combinations also had chest tube placements. From these findings, it is hypothesised that the usage of a combination of antimicrobials with coverage for aerobes and anaerobes together with chest tube placement could have a significant impact on the survival rates of pyothorax cats. Changing the 
antimicrobials based on the susceptibility testing result is also essential in achieving a better treatment outcome.

Chest tube placement is crucial in the treatment of pyothorax cases. This is evident in this study as all survivors ( 13 cats) had intermittent chest tube drainage as part of treatment (except one cat that survived without the introduction of a chest tube). In total, 18 out of 28 cats $(64.3 \%)$ had chest tube placement and 12 cats $(66.7 \%)$ that had a chest tube survived. Chest tubes were placed for an average of nine days, slightly more than the mean duration of five to seven days in other studies $[7,8,14]$. In general, the decision for chest tube removal was based on fluid production (reaching 3 to $5 \mathrm{ml} / \mathrm{kg}$ ) and clinical, radiographic or pathological improvement, which may differ on a case-by-case basis. Chest tube drainage, antimicrobial treatment and supportive care as medical therapy performed in cats in this study are considered standard treatments for cases of feline pyothorax [5,32]. Furthermore, the survival rate of cats with chest tube placement was significantly ( $p=$ $0.006)$ improved compared to those without. This might suggest that the improved survival rate of pyothorax cats is associated with chest tube placement, similar to what has been proposed in other studies [13].

Feline pyothorax is a serious life-threatening condition where in this study only 13 out of 28 cats $(46.4 \%)$ survived, similar to what has been reported earlier [8]. Both bilateral and unilateral involvement of pleural effusion in this study showed similar survival rates (around 50\%). The number of cases observed in this study is too small to draw conclusions on the relationship between the laterality of pleural effusion and survival rate. Bilateral effusion is distinctly associated with increased mortality, especially in cases of communityacquired pneumonia in humans $[5,62]$. It will be worth investigating the possibility of the laterality of pleural effusion as a prognostic factor in feline pyothorax.

Thoracic lavage with warm isotonic saline was performed in 14 out of the 18 cats with chest tubes. The risk and benefits of chest tube lavage have been a topic of discussion in several veterinary publications. An improvement was seen in pyothorax cases with chest tube lavage, where a shorter chest tube placement was needed with thoracic lavage compared to those without [32]. On the contrary, another study claimed that the evidence of thoracic lavage influencing prognosis in animals with pyothorax is not well established [41]. Another recent study discouraged thoracic lavage in felines due to the risk [8]. Possible nosocomial infection from an unintentional breach of aseptic technique and the introduction of a large amount of fluid into the pleural space, followed by the inability to retrieve it, were risks from the thoracic lavage procedure [63].

Chest tube drainage is essential for successful recovery; nonetheless, there are some associated risks. Up to $61.1 \%$ of cases that had chest tube placement had complications similar to what has been reported previously $[7,10]$. The most common complications seen among the cats in this study were lung bullae $(27.3 \%)$ and subcutaneous emphysema (27.3\%). Despite 11 pyothorax cats having developed complications, only two pyothorax cats $(18.2 \%)$ died. The underlying cause of lung bullae in this study was not identified. Lung bullae in cats are rare and have been described in association with bronchopulmonary dysplasia in a study [64]. Subcutaneous emphysema, which was seen in this study, might have been caused by the introduction and removal of the chest tube or leakage from the chest tube, as proposed in human literatures $[65,66]$. Pneumothorax cases $(18.2 \%)$ that were noted in this study could have occurred due to ruptured or iatrogenic lung bullae after thoracocentesis as seen in another study [67]. Failure in recovering $75 \%$ or more instilled thoracic lavage solution was seen in $18.2 \%$ of the cases, which could be due to chest tube kinking, chest tube obstruction or the loculation of fluid pockets. To reduce the chance of kinking or obstruction, a thoracotomy tube of the greatest diameter that can fit comfortably between intercostal spaces should be selected [32]. Minimising the risk of pneumothorax may be attained by subcutaneous insertion of the chest tube through the skin two or more intercostal spaces caudal to the site where the tube enters the thoracic cavity [9]. Caution and constant monitoring should be practiced to prevent chest tube complications such 
as iatrogenic trauma when the chest tube is inadvertently removed or an infection from aseptic thoracocentesis.

Surgical thoracotomy is indicated in cases where medical therapy has failed, or when there are extensively loculated effusions on thoracic ultrasonography or post-drainage radiographs or when there is evidence of mediastinal or pulmonary abscesses on thoracic radiographs $[14,68]$. In this study, one cat underwent surgical thoracotomy with lung lobectomy (to remove a lung abscess). The surgical procedures were indicated as the cat's condition was deteriorating despite the fact that medical treatment for pyothorax and surgical repair of concurrent diaphragmatic hernia were performed. Intercostal thoracostomy or median sternotomy for lavage, debridement and removal of the primary cause was not performed in other cases for the patients as it was not indicated, or the patient was too unstable to undergo general anaesthesia or due to the owner's financial constraints.

The current study has several limitations. The risk factor was not analysed in this study as the number of cases in this study was limited and crucial information regarding the patient was limited. The diagnostic workup performed in this study was limited by clients' financial constraints and the availability of laboratory equipment and was only performed upon clinicians' request. Testing for viruses such as feline immunodeficiency virus and feline leukaemia virus was not performed for every patient; therefore, the association between pyothorax and virus status was undetermined in this study. The immunosuppressive potential of both the viruses in cats with pyothorax remains unknown. Having a diagnosis that includes the comprehensive history of the patient, viral testing and the inclusion of other diagnostic techniques such as polymerase chain reaction (PCR) will be useful and allows a more comprehensive investigation for prospective studies. The current study was unable to include the investigation of other plausible causes of pyothorax and emerging pathogens of respiratory interest in cat species, including fungal infection [7], respiratory mycoplasma [11], Haemophilus sp. [69], lungworm [70], larva migrans [7], anaerobes [14] and foreign body migration [13]. These pathogens can cause pyothorax directly or indirectly via parapneumonic extended infection into the pleural cavity. The role of these pathogens should be investigated in future prospective studies to provide an overall picture on the causative agents of feline pyothorax. It is worth mentioning that Bordetella bronchiseptica would have grown using the culture protocol in the present study, but it was not reported in any of the cases.

\section{Conclusions}

Identification and antimicrobial susceptibility testing of isolates from pleural samples provides useful information that is needed for the selection of antimicrobials. Amoxicillinclavulanate has good antimicrobial susceptibility. Amoxicillin-clavulanate was the recommended antimicrobial against the aerobic bacteria that were found in this study and should be given in combination with antimicrobials that cover anaerobic bacteria. Epidemiology, virulence, pathogenesis and prognostic factors of pyothorax in cats will be worth investigating. Greater survival outcomes of cats were associated with initial stabilisation with oxygen supplementation and the combination of chest tube placement and aspiration, intravenous fluid and antimicrobial therapy. The definitive aetiology of feline pyothorax remains unidentified in most cases and ample room for future research exists in characterising the clinical presentation, specific radiological findings and predictive value of pleural fluid characteristics of feline pyothorax to establish a better understanding of the aetiopathogenesis of feline pyothorax in the Malaysian setting.

Author Contributions: Conceptualisation: J.J.S., S.F.L., S.O., M.W. and M.W.A.; Data curation: J.J.S.; Formal Analysis: J.J.S. and M.W.A.; Investigation: J.J.S.; Methodology: J.J.S., S.F.L. and M.W.A.; Project administration: J.J.S.; Resources: J.J.S., S.F.L., M.W.A.; Software: J.J.S., S.F.L. and M.W.A.; Supervision: S.F.L., S.O., M.W. and M.W.A.; Validation: S.F.L., S.O., M.W. and M.W.A.; Visualisation: J.J.S.; Writing-Original Draft: J.J.S.; Writing—Review and Editing: J.J.S., S.F.L., S.O., M.W. and M.W.A. All authors have read and agreed to the published version of the manuscript. 
Funding: This research received no external funding.

Institutional Review Board Statement: Not applicable.

Informed Consent Statement: This work involved the use of patient data of non-experimental animals only (owned), and followed established internationally recognised high standards ('best practice') of individual veterinary clinical patient care. Ethical approval from a committee was not necessarily required. Verbal informed consent was obtained from the pet owners to use the patients' data to report this work.

Data Availability Statement: The datasets used and/or analysed during the current study are available from the corresponding author upon reasonable request.

Acknowledgments: The authors would like to thank the staff members of Veterinary Bacteriology Laboratory, Mohd Azri Roslan, Krishnammah Kuppusamy and Nurabiatuladawiyah Rosli.

Conflicts of Interest: The authors declare no conflict of interest.

$\begin{array}{ll}\text { Abbreviations } \\ \text { spp. } & \text { Species (plural) } \\ \text { BCS } & \text { Body condition score } \\ \text { RL } & \text { Reference limit } \\ \text { RBC } & \text { Red blood cell } \\ \text { PCV } & \text { Packed cell volume } \\ \text { CWCC } & \text { Complete white cell count } \\ \text { WBC } & \text { White blood cell } \\ \text { ALT } & \text { Alanine transaminase } \\ \text { ALP } & \text { Alkaline phosphatase } \\ \text { GGT } & \text { Gamma glutamyl transferase } \\ \text { AST } & \text { Aspartate transaminase } \\ \text { TP } & \text { Total protein } \\ \text { A:G } & \text { Albumin:globulin ratio } \\ \text { SE } & \text { Standard error } \\ \text { g } & \text { Gram } \\ \text { L } & \text { Litre } \\ \text { mmol } & \text { Millimoles } \\ \text { IV } & \text { Intravenous } \\ \text { PO } & \text { Per oral } \\ \text { SQ } & \text { Subcutaneous } \\ \text { n } & \text { Sample size } \\ \text { FeLV } & \text { Feline leukaemia virus } \\ \text { FIV } & \text { Feline immunodeficiency virus } \\ \text { UK } & \text { United Kingdom } \\ \text { PCR } & \text { Polymerase chain reaction } \\ & \end{array}$

\section{References}

1. Alashraf, A.R.; Lau, S.F.; Khor, K.H.; Khairani-Bejo, S.; Bahaman, A.R.; Roslan, M.A.; Rahman, M.S.A.; Goh, S.H.; Radzi, R. Serological Detection of Anti-Leptospira Antibodies in Shelter Cats in Malaysia. Top. Companion Anim. Med. 2019, $34,10-13$. [CrossRef]

2. Sivagurunathan, A.; Atwa, A.M.; Lobetti, R. Prevalence of feline immunodeficiency virus and feline leukaemia virus infection in Malaysia: A retrospective study. J. Feline Med. Surg. Open Rep. 2018, 4, 2055116917752587. [CrossRef] [PubMed]

3. Tan, S.M.L.; Stellato, A.C.; Niel, L. Uncontrolled outdoor access for cats: An assessment of risks and benefits. Animals 2020, 10, 258. [CrossRef]

4. $\quad$ Debbra, M.; Matsura, Y.; Shariffah, N.; Muhammad Nazri, K.; Azjeemah Bee, S.H.; Sharil Azwan, M.Z.; Fakhrulisham, R. Assessing the status of pet ownership in the community of Putrajaya. Malays. J. Vet. Res. 2019, 10, 61-71.

5. Stillion, J.R.; Letendre, J.A. A clinical review of the pathophysiology, diagnosis, and treatment of pyothorax in dogs and cats. J. Vet. Emerg. Crit. Care 2015, 25, 113-129. [CrossRef] [PubMed]

6. Randolph, M.B. The Thoracic Cavity. In The Cat: Clinical Medicine and Management; Little, S., Ed.; W.B. Saunders: Saint Louis, MO, USA, 2012; pp. 892-913, ISBN 978-1-4377-0660-4. 
7. Barrs, V.R.; Allan, G.S.; Martin, P.; Beatty, J.A.; Malik, R. Feline pyothorax: A retrospective study of 27 cases in Australia. J. Feline Med. Surg. 2005, 7, 211-222. [CrossRef]

8. Waddell, L.S.; Brady, C.A.; Drobatz, K.J. Risk factors, prognostic indicators, and outcome of pyothorax in cats: 80 cases (1986-1999). J. Am. Vet. Med Assoc. 2002, 221, 819-824. [CrossRef] [PubMed]

9. Gorris, F.; Faut, S.; Daminet, S.; De Rooster, H.; Saunders, J.H.; Paepe, D. Pyothorax in cats and dogs. Vlaams Diergeneeskd. Tijdschr. 2017, 86, 183-197. [CrossRef]

10. Odunayo, A. Pyothorax. In August's Consultations in Feline Internal Medicine; Little, S., Ed.; W.B. Saunders: Saint Louis, MO, USA, 2016; Volume 7, ISBN 9780323226530.

11. Gulbahar, M.Y.; Gurturk, K. Pyothorax associated with a Mycoplasma sp and Arcanobacterium pyogenes in a kitten. Aust. Vet. J. 2002, 80, 344-345. [CrossRef] [PubMed]

12. Foster, S.F.; Martin, P.; Allan, G.S.; Barrs, V.R.; Malik, R. Lower respiratory tract infections in cats: 21 cases (1995-2000). J. Feline Med. Surg. 2004, 6, 167-180. [CrossRef] [PubMed]

13. Epstein, S.E.; Balsa, I.M. Canine and Feline Exudative Pleural Diseases. Vet. Clin. N. Am. Small Anim. Pract. 2020, 50, 467-487. [CrossRef]

14. Demetriou, J.L.; Foale, R.D.; Ladlow, J.; McGrotty, Y.; Faulkner, J.; Kirby, B.M. Canine and feline pyothorax: A retrospective study of 50 cases in the UK and Ireland. J. Small Anim. Pract. 2002, 43, 388-394. [CrossRef] [PubMed]

15. Epstein, S.E. Exudative pleural diseases in small animals. Vet. Clin. N. Am. Small Anim. Pract. 2014, 44, 161-180. [CrossRef] [PubMed]

16. Holloway, S.; Trott, D.; Shipstone, M.; Barrs, V.; Malik, R.; Burrows, M. Antibiotic Prescribing Detailed Guideline; Australasian Infectious Disease Advisory Panel: St. Lucia, Australia, 2013.

17. Gaskell, R.M.; Radford, A.D.; Dawson, S. Feline Infectious Respiratory Disease. In Feline Medicine and Therapeutics; Chandler, E.A., Gaskell, C.J., Gaskell, R.M., Eds.; John Wiley \& Sons, Ltd.: Hoboken, NJ, USA, 2004; pp. 577-595, ISBN 9780470690727.

18. Crowe, J.E. Viral pneumonia. In Kendig Chernick's Disord. Respir. Tract. Child.; Chernick, V., Boat, T.F., Wilmott, R.W., Bush, A., Eds.; W.B. Saunders: Philadelphia, PA, USA, 2012; pp. 453-460, ISBN 978-0-7216-3695-5.

19. Racklyeft, D.J.; Raidal, S.; Love, D.N. Towards an understanding of equine pleuropneumonia: Factors relevant for control. Aust. Vet. J. 2000, 78, 334-338. [CrossRef] [PubMed]

20. Berry, C.R. Interpreting small animal thoracic radiographs. Proced. Pro/NAVC Clin. Br. 2010, 65-70. Available online: https: //www.cliniciansbrief.com/article/interpreting-small-animal-thoracic-radiographs (accessed on 1 August 2021).

21. Watts, J.L. Performance Standards for Antimicrobial Disk and Dilution Susceptibility Tests for Bacteria Isolated from Animals, 3rd ed.; Clinical and Laboratory Standards Institute (CLSI): Wayne, PA, USA, 2008; ISBN 9781562386597.

22. Barrs, V.R.; Beatty, J.A. Feline pyothorax-New insights into an old problem: Part 1. Aetiopathogenesis and diagnostic investigation. Vet. J. 2009, 179, 163-170. [CrossRef]

23. Kuhajda, I.; Zarogoulidis, K.; Tsirgogianni, K.; Tsavlis, D.; Kioumis, I.; Kosmidis, C.; Tsakiridis, K.; Mpakas, A.; Zarogoulidis, P.; Zissimopoulos, A.; et al. Lung abscess-etiology, diagnostic and treatment options. Ann. Transl. Med. 2015, 3. [CrossRef]

24. Arroyo, M.G.; Slovis, N.M.; Moore, G.E.; Taylor, S.D. Factors Associated with Survival in 97 Horses with Septic Pleuropneumonia. J. Vet. Intern. Med. 2017, 31, 894-900. [CrossRef]

25. Wohleb, E.S.; McKim, D.B.; Sheridan, J.F.; Godbout, J.P. Monocyte trafficking to the brain with stress and inflammation: A novel axis of immune-to-brain communication that influences mood and behavior. Front. Neurosci. 2015, 8, 447. [CrossRef]

26. Chiu, S.; Bharat, A. Role of monocytes and macrophages in regulating immune response following lung transplantation. Curr. Opin. Organ. Transplant. 2016, 21, 239-245. [CrossRef]

27. Savigny, M.; Macintire, D.K. Human Albumin therapy in Hypoalbuminemic Dogs. Stand. Care Emerg. Crit. Care Med. $2006,8,5$.

28. Ottenjann, M.; Weingart, C.; Arndt, G.; Kohn, B. Characterization of the anemia of inflammatory disease in cats with abscesses, pyothorax, or fat necrosis. J. Vet. Intern. Med. 2006, 20, 1143-1150. [CrossRef]

29. Gorris, F.; Faut, S.; De Rooster, H.; Vandervekens, E.; Bosmans, T.; Daminet, S.; Smets, P.; Paepe, D. Two cases of feline pyothorax: Medical versus surgical treatment and associated challenges. Vlaams Diergeneeskd. Tijdschr. 2017, 86, 162-172. [CrossRef]

30. Thrall, D.E. Textbook of Veterinary Diagnostic Radiology-E-Book; Elsevier Health Sciences: Amsterdam, The Netherlands, 2017.

31. Beatty, J.; Barrs, V. Pleural effusion in the cat. A practical approach to determining aetiology. J. Feline Med. Surg. 2010, $12,693-707$. [CrossRef]

32. Barrs, V.R.; Beatty, J.A. Feline pyothorax-New insights into an old problem: Part 2. Treatment recommendations and prophylaxis. Vet. J. 2009, 179, 171-178. [CrossRef]

33. Woods, S.J.; Spriet, M.; Safra, N.; Cissell, D.D.; Borjesson, D.L. Hounsfield units are a useful predictor of pleural effusion cytological type in dogs but not in cats. Vet. Radiol. Ultrasound 2018, 59, 405-411. [CrossRef] [PubMed]

34. Briola, C.; Zoia, A.; Rocchi, P.; Caldin, M.; Bertolini, G. Computed tomography attenuation value for the characterization of pleural effusions in dogs: A cross-sectional study in 58 dogs. Res. Vet. Sci. 2019, 124, 357-365. [CrossRef] [PubMed]

35. Schultz, R.M.; Zwingenberger, A. Radiographic, computed tomographic, and ultrasonographic findings with migrating intrathoracic grass awns in dogs and cats. Vet. Radiol. Ultrasound 2008, 49, 249-255. [CrossRef]

36. Walker, A.L.; Jang, S.S.; Hirsh, D.C. Bacteria associated with pyothorax of dogs and cats: 98 cases (1989-1998). J. Am. Vet. Med. Assoc. 2000, 216, 359-363. [CrossRef]

37. Ahmed, A.E.H.; Yacoub, T.E. Empyema thoracis. Clin. Med. Insights Circ. Respir. Pulm. Med. 2010, 4, 75-84. [CrossRef] [PubMed] 
38. Razali, K.; Kaidi, R.; Abdelli, A.; Menoueri, M.N.; Ait-Oudhia, K. Oral flora of stray dogs and cats in Algeria: Pasteurella and other zoonotic bacteria. Vet. World 2020, 13, 2806-2814. [CrossRef]

39. Lloret, A.; Egberink, H.; Addie, D.; Belák, S.; Boucraut-Baralon, C.; Frymus, T.; Gruffydd-Jones, T.; Hartmann, K.; Hosie, M.J.; Lutz, H.; et al. Pasteurella Multocida Infection in Cats: ABCD guidelines on prevention and management. J. Feline Med. Surg. 2013, 15, 570-572. [CrossRef]

40. Frymus, T.; Addie, D.D.; Boucraut-Baralon, C.; Egberink, H.; Gruffydd-Jones, T.; Hartmann, K.; Horzinek, M.C.; Hosie, M.J.; Lloret, A.; Lutz, H.; et al. Streptococcal infections in cats: ABCD guidelines on prevention and management. J. Feline Med. Surg. 2015, 17, 620-625. [CrossRef]

41. Sykes, J.E. Bacterial Bronchopneumonia and Pyothorax. In Canine and Feline Infectious Diseases; Sykes, J.E., Ed.; W.B. Saunders: Saint Louis, MO, USA, 2014; pp. 847-858, ISBN 978-1-4377-0795-3.

42. Rzewuska, M.; Czopowicz, M.; Kizerwetter-wida, M.; Chrobak, D.; Błaszczak, B.; Binek, M. Multidrug resistance in Escherichia coli strains isolated from infections in dogs and cats in Poland (2007-2013). Sci. World J. 2015, 2015, 408205. [CrossRef]

43. Valat, C.; Drapeau, A.; Beurlet, S.; Bachy, V.; Boulouis, H.J.; Pin, R.; Cazeau, G.; Madec, J.Y.; Haenni, M. Pathogenic Escherichia coli in Dogs Reveals the Predominance of ST372 and the Human-Associated ST73 Extra-Intestinal Lineages. Front. Microbiol. 2020, 11, 580. [CrossRef]

44. Brooks, J.W.; Roberts, E.L.; Kocher, K.; Kariyawasam, S.; DebRoy, C. Fatal pneumonia caused by Extraintestinal Pathogenic Escherichia coli (ExPEC) in a juvenile cat recovered from an animal hoarding incident. Vet. Microbiol. 2013, 167, 704-707. [CrossRef]

45. Highland, M.A.; Byrne, B.A.; DebRoy, C.; Samitz, E.M.; Peterson, T.S.; Oslund, K.L. Extraintestinal pathogenic Escherichia coli-induced pneumonia in three kittens and fecal prevalence in a clinically healthy cohort population. J. Vet. Diagn. Investig. 2009, 21, 609-615. [CrossRef]

46. Kimura, R.; Hayashi, Y.; Takeuchi, T.; Shimizu, M.; Iwata, M.; Tanahashi, J.; Ito, M. Pasteurella multocida septicemia caused by close contact with a domestic cat: Case report and literature review. J. Infect. Chemother. 2004, 10, 250-252. [CrossRef]

47. Liu, W.; Chemaly, R.F.; Tuohy, M.J.; LaSalvia, M.M.; Procop, G.W. Pasteurella multocida Urinary Tract Infection with Molecular Evidence of Zoonotic Transmission. Clin. Infect. Dis. 2003, 36, e58-e60. [CrossRef]

48. Miyoshi, S.; Hamada, H.; Miyoshi, A.; Ito, R.; Hamaguchi, N.; Murakami, S.; Miyamoto, H.; Takeuchi, T.; Okura, T.; Higaki, J. Pasteurella multocida pneumonia: Zoonotic transmission confirmed by molecular epidemiological. Geriatr. Gerontol. Int. 2012, 12, 159-163. [CrossRef]

49. Hariharan, H.; Hariharan, S.H. Zoonotic bacteria associated with cats. Vet. Med. Open J. 2017, 2, 68-75. [CrossRef]

50. Bélanger, L.; Garenaux, A.; Harel, J.; Boulianne, M.; Nadeau, E.; Dozois, C.M. Escherichia coli from animal reservoirs as a potential source of human extraintestinal pathogenic E. coli. FEMS Immunol. Med. Microbiol. 2011, 62, 1-10. [CrossRef]

51. Davies, H.E.; Davies, R.J.O.; Davies, C.W.H. Management of pleural infection in adults: British Thoracic Society pleural disease guideline 2010. Thorax 2010, 65, ii41-ii53. [CrossRef]

52. Chapman, S.J.; Davies, R.J.O. The management of pleural space infections. Respirology 2004, 9, 4-11. [CrossRef]

53. Moyaert, H.; de Jong, A.; Simjee, S.; Rose, M.; Youala, M.; El Garch, F.; Vila, T.; Klein, U.; Rzewuska, M.; Morrissey, I. Survey of antimicrobial susceptibility of bacterial pathogens isolated from dogs and cats with respiratory tract infections in Europe: ComPath results. J. Appl. Microbiol. 2019, 127, 29-46. [CrossRef] [PubMed]

54. Aarestrup, F.M.; Bager, F.; Jensen, N.E.; Madsen, M.; Meyling, A.; Wegener, H.C. Surveillance of antimicrobial resistance in bacteria isolated from food animals to antimicrobial growth promoters and related therapeutic agents in Denmark. Apmis 1998, 106, 606-622. [CrossRef]

55. Hwang, I.Y.; Ku, H.O.; Lim, S.K.; Park, C.K.; Jung, G.S.; Jung, S.C.; Nam, H.M. Species distribution and resistance patterns to growth-promoting antimicrobials of enterococci isolated from pigs and chickens in Korea. J. Vet. Diagn. Investig. 2009, 21, 858-862. [CrossRef]

56. Han, Y.; Zhou, Z.C.; Zhu, L.; Wei, Y.Y.; Feng, W.Q.; Xu, L.; Liu, Y.; Lin, Z.J.; Shuai, X.Y.; Zhang, Z.J.; et al. The impact and mechanism of quaternary ammonium compounds on the transmission of antibiotic resistance genes. Environ. Sci. Pollut. Res. 2019, 26, 28352-28360. [CrossRef] [PubMed]

57. Guardabassi, L.; Schwarz, S.; Lloyd, D.H. Pet animals as reservoirs of antimicrobial-resistant bacteria. J. Antimicrob. Chemother. 2004, 54, 321-332. [CrossRef] [PubMed]

58. Valiakos, G.; Pavlidou, E.; Zafeiridis, C.; Tsokana, C.N.; Del Rio Vilas, V.J. Antimicrobial practices among small animal veterinarians in Greece: A survey. One Health Outlook 2020, 2, 1-8. [CrossRef] [PubMed]

59. Lappin, M.R.; Blondeau, J.; Boothe, D.; Breitschwerdt, E.B.; Guardabassi, L.; Lloyd, D.H.; Papich, M.G.; Rankin, S.C.; Sykes, J.E.; Turnidge, J.; et al. Antimicrobial use Guidelines for Treatment of Respiratory Tract Disease in Dogs and Cats: Antimicrobial Guidelines Working Group of the International Society for Companion Animal Infectious Diseases. J. Vet. Intern. Med. 2017, 31, 279-294. [CrossRef]

60. Hawkins, E.C.; Fossum, T.W. Medical and surgical management of pleural effusion. Kirk's Curr. Vet. Ther. Small Anim. Pract. XIII 2000, 13, 819-824.

61. Boyle, T.E.; Hawkins, E.C. Feline pyothorax. Stand. Care Emerg. Crit. Care Med. 2005, 7, 7-12.

62. DeBiasi, E.M.; Pisani, M.A.; Murphy, T.E.; Araujo, K.; Kookoolis, A.; Argento, A.C.; Puchalski, J. Mortality among patients with pleural effusion undergoing thoracentesis. Eur. Respir. J. 2015, 46, 495-502. [CrossRef] 
63. MacPhail, C.M. Medical and Surgical Management of Pyothorax. Vet. Clin. North. Am. Small Anim. Pract. 2007, 37, 975-988. [CrossRef] [PubMed]

64. Moores, A.L. Lung. In Feline Soft Tissue and General Surgery; Langley-Hobbs, S.J., Demetriou, J.L., Ladlow, J., Eds.; W.B. Saunders: Philadelphia, PA, USA, 2014; pp. 541-556, ISBN 978-0-7020-4336-9.

65. Ringvold, C.H.O.; Weinreich, U.M. A case report of tardive subcutaneous emphysema in relation to iatrogenic pneumothorax. SAGE Open Med. Case Rep. 2019, 7, 2050313X19870970. [CrossRef]

66. Sherman, A.; Holt, D.; Drobatz, K.; Mison, M. Evaluation of Jackson-Pratt Thoracostomy Drains Compared with Traditional Trocar Type and Guidewire-Inserted Thoracostomy Drains. J. Am. Anim. Hosp. Assoc. 2020, 56, 92-97. [CrossRef]

67. Rehbein, S.; Manchi, G.; Gruber, A.D.; Kohn, B. Successful Treatment of Pneumothorax in a Dog with Sterile Pleural Fibrosis Caused by Chylothorax. Front. Vet. Sci. 2019, 6, 278. [CrossRef]

68. Doyle, R.S.; Bellenger, C.R.; Campoy, L.; McAllister, H. Pyothorax in a cat managed by intrathoracic debridement and postoperative ventilatory support. Ir. Vet. J. 2005, 58, 211-215. [CrossRef]

69. Reed, N. Chronic Rhinitis in the Cat: An Update. Vet. Clin. Small Anim. Pract. 2020, 50, 311-329. [CrossRef]

70. Di Cesare, A.; Di Francesco, G.; Frangipane di Regalbono, A.; Eleni, C.; De Liberato, C.; Marruchella, G.; Iorio, R.; Malatesta, D.; Romanucci, M.R.; Bongiovanni, L.; et al. Retrospective study on the occurrence of the feline lungworms Aelurostrongylus abstrusus and Troglostrongylus spp. in endemic areas of Italy. Vet. J. 2015, 203, 233-238. [CrossRef] 